\title{
Inglês instrumental: a leitura para fins acadêmicos na enfermagem
}

\author{
Adilia Maria Pires Sciarra*
}

A relevância da língua inglesa como instrumento de acesso ao conhecimento escrito no mundo acadêmico motivou sua inserçáo junto da Informática, como parte de um tripé que compóe a disciplina de Metodologia Científica. Desta forma o Inglês Instrumental foi introduzido como parte de componente curricular logo no primeiro ano da graduaçáo em Enfermagem, isto é, como oportunidade de um refinamento ou aperfeiçoamento da aprendizagem de língua estrangeira para os alunos recém-aprovados em um conceituado vestibular no estado de Sáo Paulo.

O curso de Inglês Instrumental ou ESP (English for Specific Purposes) é um curso que se diferencia dos demais porque é uma abordagem ao ensino de língua inglesa através da qual todas as decisóes sobre o conteúdo e o método aplicados são baseadas na razão por que o aluno aprende.

Nesta abordagem, o foco da aprendizagem está direcionado a um recorte das quatro habilidades que compóem o processo de comunicação humana: Ouvir, Falar, Ler e Escrever. Assim, com base no pressuposto da formação dos alunos da Enfermagem também na área acadêmica, o curso está elaborado na necessidade do desenvolvimento do recorte da habilidade em Leitura.

O Course Design está estruturado da seguinte forma: inicialmente, apoiado no aprendizado das principais estratégias de leitura e habilidades linguísticas da língua inglesa comparadas à língua portuguesa e, no final, o acesso e a prática aos dispositivos tecnológicos facilitados pela rede mundial dos computadores, ou seja, pela Internet.
Segundo Grellet, 1981, a leitura deve ser definida como um processo de entender, interpretar algo escrito. Portanto, entender um texto acadêmico escrito em língua estrangeira pressupóe determinadas questóes que envolvem a leitura, que quando trabalhadas no Instrumental são preenchidas por elementos determinados.

Tenho trabalhado no enfoque de Inglês Instrumental junto ao Curso de Graduação em Enfermagem da Faculdade de Medicina de São José do Rio Preto, elaborando material específico, no gênero acadêmico-científico, na disciplina de metodologia de pesquisa. No final da prática teórica, os alunos têm a oportunidade de aperfeiçoar o conhecimento das principais estruturas escritas da língua inglesa mediante os dispositivos tecnológicos via WEB, por meio dos quais puderam também elaborar um levantamento de vocabulário geral e específico voltado para a Enfermagem: "Terminologia Genérica e Específica em Enfermagem-Glossário Inglês-Português".

Este glossário transformou-se em publicação divulgada em 2011, fazendo parte das comemoraçóes dos 20 anos da graduação em Enfermagem da FAMERP.

A cada ano temos fortalecido parcerias para divulgação da importância do inglês junto à graduaçấo e pós-graduação da Enfermagem da FAMERP, fato que tem contribuído para a conquista da excelência de ensino, pesquisa e extensão da Enfermagem FAMERP, destacada entre as melhores faculdades de enfermagem do país.

*Professora com graduação em Letras Anglo-Portuguesa pela Universidade de Maringá, PR, especialista pela PUC/SP no ensino de Lingua Instrumental para fins acadêmicos: Inglês, Português. Desenvolve o ensino de Inglês Instrumental na graduação do curso de Enfermagem por oito anos e por 10 anos atua no ensino de língua inglesa para fins acadêmicos na Faculdade de Medicina. Atualmente voltada para o conhecimento e o uso da tecnologia, ou seja, E-Learning aplicado no ensino-aprendizagem de Anatomia Obstétrica direcionado à Enfermagem, desenvolve o estímulo dos alunos no aprendizado da Lingua Inglesa como importante instrumento na globalização do conhecimento humano junto da tecnologia 